\title{
Study of C/N Ratio Effect on Biogas Production of Carica Solid Waste by SS-AD Method And LS-AD
}

\author{
Bakti Jos ${ }^{1, *}$, Fariha Hundagi $^{1}$, Rizqi Pindy Wisudawati ${ }^{1}$, Budiyono $^{1}$, and Siswo Sumardiono ${ }^{1}$ \\ ${ }^{1}$ Departement of Chemical Engineering, Faculty of Engineering, Diponegoro University, 50239, Semarang, Indonesia
}

\begin{abstract}
Biogas is a renewable energy which can be used as an alternative source to replace fossil fuels. Recently, the use of energy has become an important issue because the oil sources and natural gas are depleting. Utilization of carica waste to produce biogas can reduce the consumption of commercial energy sources such as kerosene as well as the use of firewood. Biogas is produced by the process of organic material digestion by certain anaerobic bacterial activity in anaerobic digester. In this study we studied the influence of LS-AD and SS-AD methods, the effect of $\mathrm{C} / \mathrm{N}$ ratio on biogas yield obtained and kinetics of biogas production reaction. The study was conducted by making a total solid variation of $7 \%, 9 \%, 11 \%, 13 \%$, $19 \%, 21 \%, 23 \%$ and $\mathrm{C} / \mathrm{N}$ ratio 25 and 30 . The study started with carica waste collection process and examination of the total composition of solids and water content. Thereafter, calculation and determination of variation of $\mathrm{C} / \mathrm{N}$ ratio by mixing the substrate with inoculum and urea into the reactor. Observe the volume of biogas produced every two-day intervals. The highest biogas production rate of $1.7825 \mathrm{ml} / \mathrm{g}$ TS day was obtained from carica solid waste variable by liquid state anaerobic disgestion and C/N 25 .
\end{abstract}

\section{Introduction}

Energy is a fundamental need for human survival. World oil prices and fuel requirements are increasing while crude oil reserves are depleting, so that sustainable energy supply has become one of the main challenges that humans will face in the future [26]. This moves the current economy towards alternative energy sources [4]. One of the alternatives is the utilization of renewable energy or that can be renewed energy [21]. Renewable energy source is one of environmentally friendly energy.

One of the sustainable biomass utilizations as a renewable energy source is biogas. Flexible renewable energy sources are derived from anaerobic digestion of manure, waste, residue, energy crops, water weeds [26, 38]. Biogas is a carbon-neutral source One of renewable energy, generated from the anaerobic digestion process of biodegradable waste, plant biomass, crop residues and manure. The main compositions of biogas are $\mathrm{CH}_{4}(60-$ $70 \%$ ) and $\mathrm{CO}_{2}(28-38 \%)$ and various gas products such as $\mathrm{H}_{2} \mathrm{~S}$ and $\mathrm{N}_{2}$. Biogas production raw materials generally come from agricultural waste such as rice husks [31], rice straw [8,33], wheat straw [15] and livestock waste such as cow dung [24], sugar cane [32], Eichhornia crassipes [35], horse manure, pig manure and poultry manure [14]. There are also biogas raw materials derived from industrial waste alcohol [9-12], slaughterhouse wastes [6], fish industry waste [28], cassava starch [5], and tapioca industrial liquid waste [2, 20]. One of the industrial waste that can be processed into biogas is carica waste.

The carica fruit is commonly used for raw materials for making jams, sweets, cold drinks and cocktails $[22,29]$. From the remain of the production process it also produce another that are considered still can be utilized. One of the byproducts from the processing of candied of carica fruit is carica peels.

Carica fruit peels produced by many industries is still not utilized and become the burden of the industry. In a day, it can be produced as much as $860 \mathrm{~kg}$ of carica fruit that will produce carica peels waste as much as $200 \mathrm{~kg}$ per day. This means that within a year the peels of carica fruit obtained reaches $73,000 \mathrm{~kg}$ [16]. Therefore, these carica peels byproducts need further processing so as to have a positive impact on the industry. To produce biogas with anaerobic digestion, the decomposition of organic waste occurs in four processes simultaneously: hydrolysis, acidogenesis, acetogenesis, and methanogenesis [7, 38-39]. The purpose of this research is to know the effect of total solid and $\mathrm{C} / \mathrm{N}$ ratio toward biogas yield obtained and to analyze the kinetics of biogas production reaction $[34,39]$.

\section{Experimental}

The materials used in this research are carica waste obtained from carica making industry in Wonosobo area, while rumen cow fluid as inoculum obtained from slaughter house in Pedurungan, Semarang. The tools used are batch digester in the form of 1 liter bottle, rubber cover, hose and clamp, measuring cup, oven, scales, and statif. The independent variables in this study were $\mathrm{C} / \mathrm{N}$ ratio 25,30 , and total solids $7 \%, 9 \%, 11 \%$, $13 \%, 19 \%, 21 \%, 23 \%$. The series of research tools can be seen in Figure 1.

\footnotetext{
Corresponding author: baktijos@che.undip.ac.id
} 


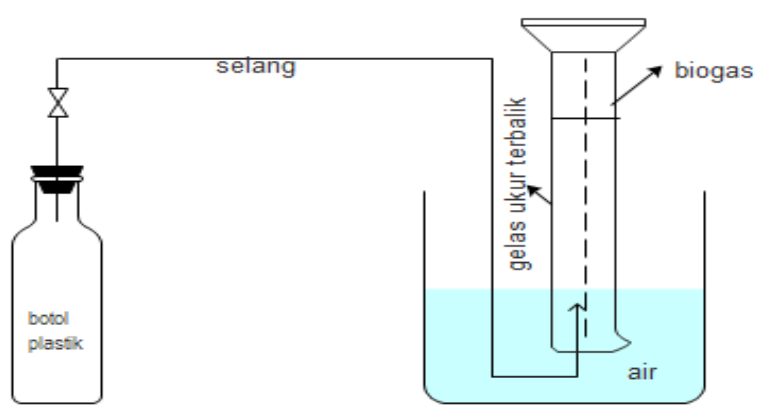

Fig 1. Research Tool Series

The implementation of this research started from the process of making carica waste (biowaste), then examined the total composition of solids and water content [37]. After that, calculation and determination of variation of $\mathrm{C} / \mathrm{N}$ ratio and also preparation of anaerobic batch reactor. Subsequently, the substrate is mixed with technical inoculum and urea to adjust the $\mathrm{C} / \mathrm{N}$ ratio. Samples that have been prepared can be put into the reactor, tightly closed to obtain anaerobic conditions, and ready to operate. During the process of processing, the volume of biogas produced each time interval of 2 (two) days is observed. The biogas volume is calculated by passing the gas into a water-filled measuring cup by utilizing the gas characteristic that is by pressing in all directions from the reactor (Boyle's Law), so that when the reactor valve is opened, the gas directly moves into the measuring cup and then being observed the volume of differences. Observation stopped after no more biogas was formed.

To determine the kinetics constant of biogas production was used Gompertz equation [30,36]. the Gompertz equation recently was found to be the most suitable model for describing the growth data of Lactobacillus plantarum and Lactobacillus acidophilus, which is written as

$$
N=\int_{0}^{t} r_{g} d t=A \cdot \exp \left\{-\exp \left[\frac{\mu_{m}}{A}(\lambda-t)+1\right]\right\}
$$

The relationship between the bacterial growth rate and the substrate utilization rate can be defined by the following equation:

$$
r_{g}=Y_{1} \cdot\left(-r_{s u}\right)
$$

On the other hand, the relationship between the substrate utilization rate and the methane production rate is

$$
-r_{s u}=Y_{2} \times r_{m}
$$

According to (2) and (3) the methane production rate can be defined as follows:

$$
r_{\mathrm{m}}=\frac{\mathrm{r}_{\mathrm{g}}}{\mathrm{r}_{1} \mathrm{x}_{2}}
$$

Thus, the cumulative methane production $M$ can be defined as

$$
M=\int_{0}^{t} r_{m} d t=\int_{0}^{t} \frac{r_{g}}{Y_{1} x_{2}} d t=\frac{1}{Y_{1} \mathbb{Y}_{2}} \int_{0}^{t} r_{g} d t
$$

If $\int_{0}^{t} r_{g} d t$ is replaced in (1), the resulting expression for the cumulative methane production is

$$
M=\frac{A}{Y_{1} Y_{2}} \cdot \exp \left\{-\exp \left[\frac{\left(\mu_{m} / Y_{1} Y_{2}\right) \cdot e}{\left(A / Y_{1} Y_{2}\right)}(\lambda-t)+1\right]\right\}
$$

The term $\overline{V_{1} Y_{2}}$ can be replaced by the term $P$, defined as the methane production potential, while $\mu_{m} / Y_{1} \times Y_{2}$ can be defined as the maximum methane production rate. Therefore, the resulting final expression is

$$
M=P \cdot \exp \left\{-\exp \left[\frac{R_{m n^{e}}}{p}(\lambda-t)+1\right]\right\}
$$

$\mathrm{P}=$ = Production of biogas cumulative, liter

A $=$ Production of biogas maximum, liter

$\mathrm{U}=$ Constant rate of production biogas maximum (liter/day)

$\lambda=$ lag phase time (time minimum to produce biogas), day

$=$ Time cumulative to produce biogas, day

$=$ Euler $(e=2.71828 \ldots)$

The equation above illustrates the equation of the biogas production rate at various observation times. Constants $\mathrm{U}, \mathrm{A}$, and $\lambda$ can be determined by non-linear regression method toward data obtained from experimental studies using Polymath 6.0 Program.

\section{Results and Discussion}

\subsection{Effect of Total Solid on $\mathrm{C} / \mathrm{N}$ ratio 25 by LS- AD method}

Daily biogas production volume varies depending on the total solid condition. This can be seen in Figure 2 which shows the daily biogas production rate at $\mathrm{C} / \mathrm{N}$ ratio 25 .

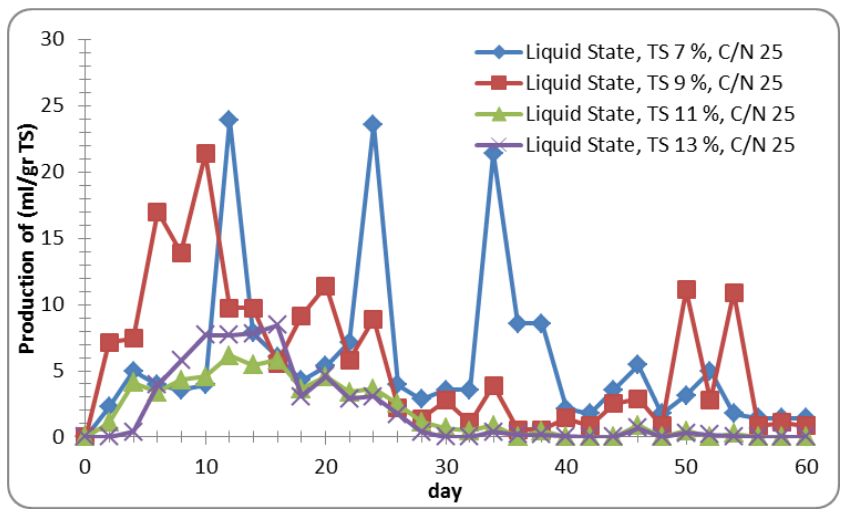

Fig 2. Daily biogas production rate $\mathrm{C} / \mathrm{N}$ ratio 25

Figure 2 shows the daily biogas yield on carica waste with a $\mathrm{C} / \mathrm{N}$ ratio of 25 . In carica waste with a solid total of $7 \%$ fluctuating biogas production tends to increase until day 12 . On the $22^{\text {nd }}$ and $34^{\text {th }}$, days the biogas production went up drastically, but on the next day until 
the $60^{\text {th }}$ day the fluctuating biogas production tended to decline but still produced biogas. In carica waste with a solid total of $9 \%$ biogas production tends to rise until day 10. However on the 12 th day the fluctuations tend to decrease until the 60th day still produce biogas. In carica waste with a solid total of $11 \%$ biogas production tends to rise until day 12 . However, on day 16 , fluctuations tend to decrease until day 60 and still producing biogas. In carica waste with a solid total of $13 \%$ biogas production tends to rise until the 14th day. However, on day 16 , fluctuations tend to decrease until day 60 and still producing biogas.

\subsection{Effect of Total Solid on $\mathrm{C} / \mathrm{N}$ ratio 25 by SS- $A D$ method}

Daily biogas production volume varies depending on the total solid condition. This can be seen in Figure 3 which shows the daily biogas production rate at $\mathrm{C} / \mathrm{N}$ ratio 25 .

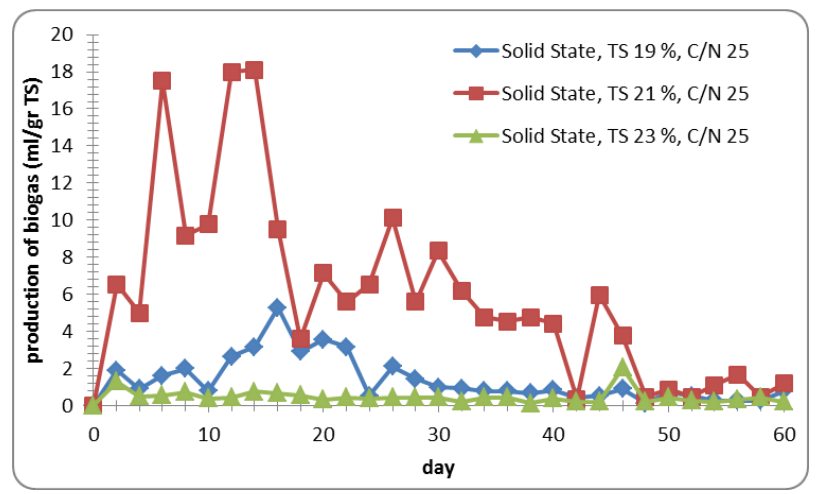

Fig 3. Daily biogas production rate $\mathrm{C} / \mathrm{N}$ ratio 25

Figure 3 shows the daily biogas yield on carica waste with a $\mathrm{C} / \mathrm{N}$ ratio of 25 . In carica waste with a solid total of $19 \%$ biogas production tends to rise until the $16^{\text {th }}$ day. However on the $18^{\text {th }}$, day the fluctuations tend to decrease until the $60^{\text {th }}$ day and still produces biogas. In carica waste with a solid total of $21 \%$ biogas production tends to increase until the $6^{\text {th }}$ day. However, on day 1,6 fluctuations tend to decrease until day 60 and still producing biogas. In carica waste with a solid total of $23 \%$ biogas production tends to stagnate or no significant change until day 60 . Where the bacteria undergo the last phase, the phase of death (death phase) began to decrease the number of bacteria, until the bacteria die completely until the biogas is not reproduced. Biogas production is most common occured in the total solid $21 \%$. This is evident where on the $12^{\text {th }}$ and $14^{\text {th }}$ day of production biogas reaches $780 \mathrm{ml}$ volume.

\subsection{Effect of $\mathrm{C} / \mathrm{N}$ ratio on Carica Wastes on Biogas Production by SS-AD Method}

Daily biogas production volume varies depending on the total solid condition. This can be seen in Figure 4 which shows the daily biogas production rate at $\mathrm{C} / \mathrm{N}$ ratio 25 and 30 .

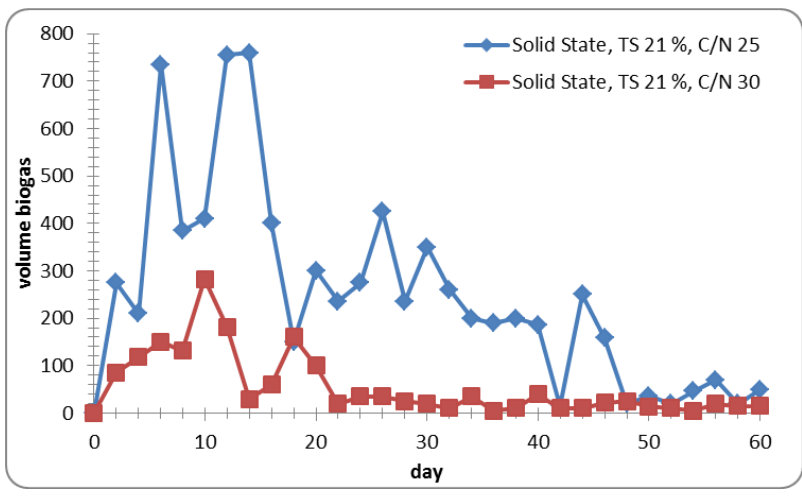

Fig 4. Daily biogas production rate

Figure 4 shows the daily biogas yield in carica solid wastes with $\mathrm{C} / \mathrm{N}$ ratio 25 and 30 . In carica waste with a $\mathrm{C} / \mathrm{N}$ ratio of 25 fluctuating biogas production tends to increase until the $14^{\text {th }}$ day. On the $16^{\text {th }}$ day the fluctuating biogas production tends to decrease. However, biogas never rises again in harike 46. And then fluctuate down to day 60 still produce biogas. In carica waste the ratio of $\mathrm{C} / \mathrm{N} 30$ biogas production increased volatile until day 10 . On the $18^{\text {th }}$ day, biogas production fluctuates tends to decline until the $60^{\text {th }}$ day and still produce biogas.

\subsection{Kinetics of Biogas Production}

By using non-linear regression method, data obtained from experiments can be obtained kinetic constants as presented in Table 4.1 as follows.

From table 1, it can be seen that the lowest Rm (biogas production rate) is a variable with a solid total of $23 \% \mathrm{C} / \mathrm{N} 25$ ratio with a value of $0.044348 \mathrm{ml} / \mathrm{g}$ TS days. Where the highest value of $\mathrm{Rm}$ is found in carica waste with a total $9 \%$ solid state liquid condition and $\mathrm{C} / \mathrm{N} 25$ ratio which value is $1.78 \mathrm{ml} / \mathrm{g}$ TS day. Thus the total solid and $\mathrm{C} / \mathrm{N}$ ratio affects the of biogas production, the time of biogas is formed also influenced by the nutrition factor given to substrates that are used as raw materials because the nutrients are toxic which can increase the $\mathrm{pH}$ and can influence the activity of bacteria to remodel the organic compound into biogas [23]. Brown, et al. (2013) also mentioned that significantly lower methane production was generated in SS-AD compared to L-AD [13]. Because a solid total value higher than $15-20 \%$ will increase the mass diffusion resistance, it will cause inhibition of hydrolysis and methanogenesis. The lower water content also causes the rapid accumulation of volatile fatty acids (VFAs) that inhibit microbial methanogens [1, 18-19]. 
Table 1. Kinetics data of biogas production reaction according to calculation of Gompretz equation

\begin{tabular}{|c|c|c|c|c|}
\hline Variable & $\mathbf{P}$ & $\mathbf{R m}$ & $\mathbf{M}$ & $\begin{array}{c}\text { M } \\
\text { calculation }\end{array}$ \\
\hline $\begin{array}{c}\text { TS 7 with } \\
\text { C/N 25 }\end{array}$ & 23.9 & 1.707 & 171.2 & 23.9 \\
\hline $\begin{array}{c}\text { TS 9 with } \\
\text { C/N 25 }\end{array}$ & 21.39 & 1.782 & 175.5 & 21.39 \\
\hline $\begin{array}{c}\text { TS 11 with } \\
\text { C/N 25 }\end{array}$ & 6.13 & 0.438 & 61.5 & 6.13 \\
\hline $\begin{array}{c}\text { TS 13 with } \\
\text { C/N 25 }\end{array}$ & 8.5 & 0.472 & 65.7 & 8.5 \\
\hline $\begin{array}{c}\text { TS 19 with } \\
\text { C/N 25 }\end{array}$ & 5.26 & 0.292 & 41.6 & 5.26 \\
\hline $\begin{array}{c}\text { TS 21 with } \\
\text { C/N 25 }\end{array}$ & 18 & 1.125 & 181.45 & 18. \\
\hline $\begin{array}{c}\text { TS 23 with } \\
\text { C/N 25 }\end{array}$ & 2.04 & 0.044 & 14.4 & 2.04 \\
\hline $\begin{array}{c}\text { TS 7 with } \\
\text { C/N 30 }\end{array}$ & 2.86 & 0.11 & 45.5 & 2.86 \\
\hline $\begin{array}{c}\text { TS 9 with } \\
\text { C/N 30 }\end{array}$ & 8.6 & 0.478 & 75.39 & 8.6 \\
\hline $\begin{array}{c}\text { TS 11 with } \\
\text { C/N 30 }\end{array}$ & 8.9 & 0.178 & 64.59 & 8.899 \\
\hline $\begin{array}{c}\text { TS 13 with } \\
\text { C/N 30 }\end{array}$ & 6.15 & 0.181 & 46.5 & 6.15 \\
\hline $\begin{array}{c}\text { TS 19 with } \\
\text { C/N 30 }\end{array}$ & 4.21 & 0.301 & 40 & 4.21 \\
\hline $\begin{array}{c}\text { TS 21 with } \\
\text { C/N 30 }\end{array}$ & 6.7 & 0.67 & 39.97 & 6.7 \\
\hline $\begin{array}{c}\text { TS 23 with } \\
\text { C/N 30 }\end{array}$ & 8.04 & 1.005 & 48.95 & 8.04 \\
\hline
\end{tabular}

From table 1 it can be seen that the value of $\mathrm{M}$ (cumulative biogas production) between $\mathrm{C} / \mathrm{N}$ ratio 25 and $\mathrm{C} / \mathrm{N}$ ratio 30 is greater with $\mathrm{C} / \mathrm{N}$ ratio 25 . Because according to Yani and Darwis (1990), microbes that play an anaerobic need nutrients to grow and develop, in the form of carbon sources and nitrogen sources [3]. The equilibrium of carbon and nitrogen in substrates used as substrates needs attention [27]. Therefore, if too much nitrogen the growth of bacteria will be inhibited, in this case especially the material which ammonian content is very high [25], whereas the substrate is only a few nitrogen, bacteria will not be able to produce the enzymes needed to synthesize the compound (substrate) containing carbon, the most optimum substrate is $\mathrm{C}: \mathrm{N} 25$ because the optimum ratio $\mathrm{C}: \mathrm{N}$ ranges from $20: 1$ to $30: 1$ [17].

\section{Conclusions}

Biogas production rate of carica solid waste is better in LS-AD condition than SS-AD. Optimum biogas production was obtained at $\mathrm{C} / \mathrm{N}$ ratio 25 compared to $\mathrm{C} / \mathrm{N}$ ratio 30 . Kinetics constant of biogas production from carica waste has the highest production rate $(\mathrm{Rm})$ constant of $1.7825 \mathrm{ml}$ gr TS day with TS $9 \%$.

Authors thank to Department of Chemical Engineering, Diponegoro University for all facilities to do this research.

\section{References}

1. A. Abbassi-Guendouz, D. Brockmann, E. Trably, C. Dumas, J.P. Delgenés, J.P. Steyer, R. Escudié, Bioresour. Technol. 111, 55-61 (2012)

2. L. Appels, J. Lauwers, J. Degrve, L. Helsen, B. Lievens, K. Willems, Renew Sustain Energy Rev. 15, 9, 4295e301 (2011)

3. M. Yani, A.A. Darwis, Diktat Teknologi Biogas. (Pusat Antar Universitas Bioteknologi, Institut Pertanian Bogor, Bogor, 1990)

4. Budiyono, I.N. Widiasa, S. Johari, Sunrso, Int J ChemBiolEng. 3, 1, 39-44 (2010)

5. Budiyono, T.D. Kusworo, Int'1 J. Sci. Eng. 2, 1, 48 (2011)

6. B. Budiyono, I.N. Widiasa, S. Johari, S. Sunarso, Int'1 J. Waste Resources (IJWR). 1, 2, 4-7 (2011)

7. L. Yang, Y. Li, Bioresource Technology. 171, 233-239 (2014)

8. A. Teghammar, G. Forgacs, I. Sarvari Horvath, M.J. Taherzadeh, Applied Energy. 116, 125-133 (2014)

9. Budiyono, I. Syaichurrozi, S. Sumardiono, World Applied Sciences Journal. 26, 11, 1464-1472 (2013a)

10. Budiyono, M.E. Pratiwi, I.N. Sinar, Alchemy Jurnal Penelitian Kimia. 9, 2, 1-12 (2013b.)

11. Budiyono, I. Syaichurrozi, S. Sumardiono, Int'l J. Eng. 27, 2, 177-184 (2014a)

12. Budiyono, I. Syaichurrozi, S. Sumardiono, Research Journal of Applied Sci. Eng. Tech. 7, 13, 2798-2805 (2014b)

13.D. Brown, Y. Li, Bioresource Technology. 127, 275-280 (2013)

14. M. Carlini, S. Castellucci, M. Moneti, Energy Procedia. 82, 811-818 (2015)

15. R. Chandra, H. Takeuchi, T. Hasegawa, R. Kumar, J Appl Energy. 94, 129-40 (2012)

16. Chasanah, Nurul, Pemanfaatan Kulit Buah Carica Untuk Pektin Di Ud. Yuassa Food Berkah Makmur (UGM, 2014)

17.D. Deublein, A. Steinhauser, Biogas from Waste and Renewable Resource (Wiley-VCH Verlag $\mathrm{GmbH}$ dan Co. KGaA, Weinheim, 2008)

18. A. Schievano, G. D'Imporzato, L. Malagutti, E. Ragalli, G. Ruboni, F. Adani, Bioresour. Technol. 101, 5728-5732 (2010)

19.F. Di Maria, G. Gigliotti, A. Sordi, C. Micale, C. Zadra, L. Massaccesi, Waste Manage. Res. 31, 869-873 (2013)

20.H.R. Rahmatul, A. Nurrokhim, N. Soewarno, S. Nurkhamidah, Jurnal Teknik Pomits. 2, 1 (2013)

21. T. Haryati, J. Wartazoa. 16, 160 - 169 (2006).

22.H. Idstein, T. Keller, P. Schrejer, J. Agric.Food.Chem. 33, 4, 663-666 (1985)

23. A.N. Ikrimah, A. Pramianshar, Inovasi Teknologi Produksi Biogas Secara Anaerobik dari Sludge Limbah Industri Pengolahan Ikan sebagai Energi Terbarukan Masa Depan (Jurusan Teknik Kimia, Fakultas Teknik, Universitas Diponegoro, Semarang, 2014) 
24. D.A. Putri, R.R. Saputro, Budiyono, International Journal of Renewable Energy Development (IJRED). 1, 2, 61-64 (2012)

25. M. Kumar, J.G. Lin, J. Hazardous Materials. 178, $1-9$ ( 2010)

26. Patowary, Dipam., W. Helen, C. Michele, D.C. Barurah, "Biogas Production from Surplus Plant Biomass Feedstock: Some Highlights of Indo-UK $R \& D$ Initiative". International Conference on Solid Waste Management. (2015)

27. J. Mata-Alvarez, J. Dosta, S. Mace, S. Astals, Crit.Rev.Biotechnol. 31, 2, 99-111 (2011)

28. M.F. Maulana, Sudarno, I.W. Wardhana, Pengaruh Pengenceran dan Pengadukan Limbah Industri Ikan Nila terhadap Peningkatan Produksi Biogas with Menggunakan Rumen Sapi sebagai Starter (Program Studi Teknik Lingkungan Universitas Diponegoro, Semarang 2013)

29. M.A. Moya-León, M. Moya, R. Herrera, Postharvest Biology and Technology. 34, 211218 (2004)

30. A. Nopharatana, P.C. Pullammanappallil, W.P. ClarkeWaste Management 27, 5, 595-603 (2007)

31. O.C. Okeh, C.O. Onwosi, F.J. Odibo, Renewable Energy. 204-208 (2013)

32. S. Sumardiono, A. Budi Riyanta, H. Hawali Abdul Matin, B. Jos, Budiyono, Increasing Biogas Production From Sugar Cane Baggase By Anaerobic Co-Digestion With Animal Manure. MATEC Web of Conferences. 101, 02014 (2017)

33. Budiyono, A. Wicaksono, A. Rahmawan, T. Djoko Kusworo, S. Sumardiono, MATEC Web of Conferences. 101, 02011 (2017)

34. T. Prasetyo, S. Sumardiono, H.A. Aji, A.Y. Pratama, Advanced Science Letters. 23, 6, 58105814 (2017).

35.S. Sumardiono, Budiyono, D.T. Mardiani, AIP Conference Proceedings. 1699, 050018 (2015).

36. Budiyono, I. Syaichurrozi, S. Sumardiono, Research J.Appl.Sci.Eng.Tech. 7, 13, 2798-2805 (2014).

37. Budiyono, I. Syaichurrozi, S. Sumardiono, Int'l. J.Eng. Transactions B: Applications. 27, 2, 177184 (2014).

38. Budiyono, I. Syaichurrozi, S. Sumardiono, World Appl.Sci.J. 26, 11, 1464-1472 (2013).

39. Syaichurrozi, Budiyono, S. Sumardiono, Bioresource Technology 149, 390-397 (2013). 